\title{
Online Marketing Impact on Micro-Enterprises: An Insight through Visibility in Search Engines
}

\author{
Artoym KOVALENKO \\ South Ural State University (National Research University), Chelyabinsk, Russia \\ insmarkets@gmail.com \\ Yuliya KUZMENKO \\ South Ural State University (National Research University), Chelyabinsk, Russia \\ polina.94@mail.ru
}

\begin{abstract}
Transforming marketing into an online format is an inevitable process of developing an information economy. The study of information flows allows using a comprehensive approach to the problems of online marketing. The activities of small businesses are characterized by various limitations, but it is an important factor in increasing the flexibility of the economy and the ability to adapt to changes. The gap in the theory and practice of conducting Internet marketing activity in micro enterprises has helped to shape the relevance of this work. The aim of the study is to research the phenomenon of visibility of Internet websites from the perspective of marketing information flows in the activities of small businesses. The article discusses the theoretical foundations of marketing information flows, Internet marketing, inbound marketing and visibility of Internet websites. The research methodology is based on the methods of marketing analysis and sociological surveys. The study was conducted on the basis of the sampling of 306 websites of small enterprises. The study examined the characteristics of the websites of small enterprises, reflecting the effectiveness of Internet marketing activities. The results show that there is a correlation between the number of applied methods of Internet marketing and the visibility of the websites of small organizations in the search engine. The existence of particular cases of the use of single methods of Internet marketing has been revealed, providing high visibility and effectiveness of Internet marketing activities of small organizations.
\end{abstract}

Keywords: online marketing, internet marketing technologies, marketing flows, visibility, search engines, micro-enterprises.

Please cite the article as follows: Kovalenko, A. and Kuzmenko, Y. (2020), "Online marketing impact on micro-enterprises: an insight through visibility in search engines", Management \& Marketing. Challenges for the Knowledge Society, Vol. 15, No. 1, pp. 38-58. D0I: 10.2478/mmcks2020-0003.

\section{Introduction}

Modern digital marketing is formed on the basis of a variety of communication channels (Halligan \& Shah 2014). Today, enterprises of various shapes and sizes use Internet marketing methods. Small micro-business organizations comprise a separate group of enterprises. This type of enterprise is virtually devoid of high-cost Internet marketing technologies - it has financial, personnel limitations, as well as limitations in its competencies. The need to use low-budget marketing technologies defines the issue of an effective combination of methods and tools that underly each technology of Internet marketing of a small micro-enterprise. Studies show that modern marketing has a flow structure (De Cleen, 2018).

Digital marketing has a form of consumer and customer flow in the channels of Internet marketing communications. The specificity of digital marketing is characterized 
by diverse communication channels - search engines, social networks, various advertising systems and measurement tools (Halligan \& Shah 2014). One of the most common indicators that determine the efficiency of Internet marketing activities is the visibility of an Internet resource in communication channels, which includes visibility in search engines (Weideman, 2006), social networks (Krstic, 2019) and other types of Internet websites. The methodological tools of digital marketing are determined by a set of interacting information flows (Berdyshev, 2010). Digital marketing methods and tools interact with each other and influencing the flow of consumers. This process is characterized by the following features:

1) Internet marketing is seen as an element that enhances and complements the characteristics of classic marketing. Internet marketing transforms the elements of classic marketing into a digital form (Kapustina \& Mosunov, 2015).

2) The development of digital marketing tools determines the possibilities in targeting advertising campaigns to narrow segments of the target audience in communication channels (Halligan \& Shah 2014). It means access to segments of the target audience, the needs of which small micro-enterprises can satisfy at a higher level than medium and large businesses (Levinson, 2007).

3) Modern marketing is characterized by interaction processes (Bagiev, 2009). Internet marketing methods enhance the effectiveness of each other. So, in the inbound marketing methodology, the effectiveness of content distribution depends on the number of communication channels used and the connections between them (Halligan \& Shah 2014).

The reasons previously presented allow the identification of a research problem. Modern marketing has a multi-channel nature (Halligan \& Shah 2014). Internet marketing methods interact within as well as between communication channels. The focus of small organizations on a single method or channel reduces the effectiveness of Internet marketing activities (Datainsight \& Avito, 2017). The survival rate of a small business in the Russian Federation depends on the ability to use marketing methods (Sidorchuk, 2013). Many authors considered marketing activities (Zemlyak, 2007) and the Internet marketing activities of small businesses (Kaya, 2019), specific aspects of Internet marketing in the form of Internet marketing tools. At the same time, the issues of the interaction of individual Internet marketing methods within the framework of communication channels were indirectly considered. In the authors' opinion, this is a gap in the study of Internet marketing activities of small businesses. Thus, it is necessary to study the interaction of methods and communication channels of Internet marketing for small businesses.

In this paper, the authors consider the connection between the methods of Internet marketing used by small micro business enterprises and the visibility of the latters' website in search engines. Effective Internet marketing factors are characterized by the interaction of Internet marketing methods in various communication channels, as noted in works on inbound marketing (Halligan \& Shah 2010; Novak et al., 2000). Thus, the aim of the research is to study the phenomenon of visibility of Internet websites from the perspective of the marketing information flow in the activities of small businesses. The list of research tasks includes the following:

1) Systematize existing research on Internet marketing activities of small businesses;

2) Identify key groups of communication channels based on the analysis of the Internet advertising market of the Russian Federation; 
3) Determine the sample, and develop and conduct an empirical study of the Internet marketing activities of small businesses.

4) Perform a basic statistical and cluster analysis of the Internet marketing activities of small businesses.

5) Perform a correlation analysis of clusters of small businesses on the effectiveness of conducting Internet marketing activities and describe the relationship between the Internet marketing methods.

The authors of this article believe that the methods of Internet marketing in communication channels with various specifics are in a state of dependence - the use of one group of methods enhances the use of another group. Based on a study of Internet marketing development in the Russian Federation (Kapustina \& Mosunov, 2015; Sovershaeva, 2014), the relationship between the use of search engine optimization methods, contextual advertising and promotion on social networks is considered.

In the first section of the article, the specific features of the development of Internet marketing methods for small businesses regarding the development of the Internet advertising market are considered. Based on a theoretical study, one can distinguish three groups of channels within which methods these are developing: search engines, social networks, and private Internet websites. Then the methodology for the analysis of empirical data and the features of the collection of empirical data in studies of Internet marketing activities is considered. Based on a combination of sociological and marketing analysis techniques, a methodology for collecting empirical data is developed. Cluster and correlation analysis methods are applied to the data collected as a result of empirical research. As a result of an empirical study, the relationship between the individual methods of Internet marketing and their influencing the visibility of Internet sites of small micro-enterprises in search engines is illustrated.

\section{Conceptual framework and hypothesis development}

The discussion starts with a common research understanding of marketing information flows to later move on to methodological tools and individual methods of Internet marketing. In the literature review, the choice of the main hypotheses of the study is rationalized.

\section{Marketing flows as a promising type of Internet marketing development in small enterprises}

Consideration of marketing from the point of view of information flows is found in classic works on marketing. Kotler \& Keller (2012) considered the information flow in various forms of advertising, personal sales and promotion. A similar view is present in another work of classical marketing. Lambin \& Schuiling (2012) considered the information flow as a flow, aligning supply and demand with each other.

It is worth noting that the works of marketing classics did not have the tools to distinguish the marketing information flow into something more than the flow of communications. In the authors of this research opinion, communication as a marketing area is the basis for the formation of the information flow but does not describe its essence. However, modern technology and the Internet allow revealing the properties of the marketing information flow.

Accordingly, this difference is taken into account in later works on the general characteristics of the marketing stream. This fact is most vividly illustrated by De Cleen, who sees flow marketing as a new approach that describes consumer behavior. The paper identifies two types of key marketing information flows (De Cleen, 2018): 
1) The flow of consumers describes the mental state in which the consumer is, both in the buying and in the using of a product.

2) The flow of customers describes the way in which modern consumers deal with consumption (in physical or digital form).

The marketing flow model is behavioral and situational, taking into account the characteristics of consumer behavior that are important for the enterprise.

The development of digital marketing has determined a surge of ideas about marketing information flow. In Novak et al. (2000), the marketing information flow is considered as kind of consumer experience in an online environment. A stream is defined as a condition that occurs during navigation on the Internet. In Novak et al (2000), authors define the information flow of marketing as a psychological state. The main characteristic of this condition is that consumers feel a balance between their skills and interaction issues. Skills should be above the critical threshold of interaction issues. This approach emphasizes the importance of usability issues for users of websites.

In the authors of this article opinion, De Cleen's ideas are most precisely developed in the methodology of inbound marketing by Halligan and Shah (2014). The researchers of Inbound marketing consider "Internet traffic" as a practice-oriented concept of the marketing information flow. Halligan and Shah identified one of the main features of marketing information flow: the source of the flow is consumers, in contrast to traditional marketing, where the sources of the flow are companies (Inbound after Outbound).

Inbound marketing is determined by an increased level of targeting: choosing the right consumers (Soegoto \& Simbolon, 2018), who are interested in interacting with the company. In this context, inbound marketing involves a holistic approach to marketing from the distribution of valuable content (content marketing) to specific methods of Internet marketing - SEO, SMM, PPC etc.

Inbound marketing has its own individual flaws. The most significant disadvantages are:

1) The difficulty for companies in certain industries to produce quality content on an ongoing basis. This type includes organizations of one-time demand, which the consumer turns to in the case of certain circumstances (tow truck services, for example).

2) Consumer's overload by information flows. The increase in the number of incoming information flows also negatively affects the consumer. The opposite effect of direct marketing is formed - the consumer receives too many notifications and stops responding to them.

However, taking the shortcomings into account, the inbound marketing methodology shifts the emphasis of competition from the direct attention of the consumer to competition within the channels of marketing communications represented by various types of Internet websites. It determines the need for the formation of sufficient visibility of the organization in various communication channels of Internet marketing.

\section{Presence in the Web: search engine visibility studies}

The concept of visibility is specific to Internet marketing. Visibility characterizes the growth of positions in search results and the success of website promotion (Weideman, 2005). The characteristics of visibility of Internet websites originate in "brand awareness", but characterize the memorability and recognition of the campaign in the communication channel.

Search engines measure the visibility of a website (Hamdulay \& Weideman, 2006). The directions of increasing the visibility of the website are based on the improvement of 
the link, technical, content, behavioral and other factors that make up the ranking of search engines.

In various studies, visibility is considered as a success factor of website promotion in search engines. In Search Engine Optimization, visibility acts as an alternative in distributing marketing budgets to promotion websites in search engines (Berman \& Katona, 2012). Statistical studies show that search engine promotion of websites to achieve visibility is described by dynamic indicators characterizing the promotion of websites in a competitive market (Berman \& Katona, 2012).

In a review of later studies of visibility, there is empirical evidence of the statistical relationship between search engine visibility and brand perception, and between search engine visibility and economic demand (Hamdar et al., 2018).

The development of search engines and Internet marketing technologies resulted in complication of market segmentation, caused the division of regional search engine results and the emergence of specific features of regional websites promotion. Search engine results are affected by a growing number of factors: inclusion in regional directories (Google Business), the presence of additional points of contact with the target audience (social networks, video services). For example, Slivar and Doric (2011) reflect aspects of changing the visibility of regional and national websites.

Mechanisms for accounting and ranking information used in search engines are used in various areas. Visibility research goes beyond search engine promotion. Notable is the work on the application of search engine optimization technologies in the ranking of scientific information - OR-SEO ontology - for the collection of metadata for scientific events (Fathalla et al., 2019).

Promotion of the website through increased visibility is uncertain and depends on a variety of factors (presence in social networks, reference impact, commercial factors and other elements of internal and external search engine optimization). The process of developing the website visibility is uncertain as well, there are no clearly formalized methods and rules due to the constant development and improvement of communication channels. With this in mind, the authors of this article agree that high visibility in search engines is associated with behavioural factors - activity and achieving the goals of the visitor on the website (the visitor finds what he is looking for). According to the theoretical survey, visibility is an integral indicator of the success of Internet resource promotion in communication channels.

Various factors influence the visibility rate, but theoretical studies do not indicate the degree of influence of these factors. Thus, the authors of this study propose the following hypothesis:

H1: There is a dependency between the number of communication channels (Internet marketing methods) and search engine visibility. The interaction of these factors affects the effectiveness of Internet marketing activities of small enterprises.

\section{Internet marketing in small micro-enterprises of the Russian Federation}

The literature on Internet marketing for small businesses shows an orientation on the types of methods that have a low budget nature or a high level of targeting. The works of Zemlyak, Tretyakova, and Sovershaeva are worth mentioning among the researchers of Internet marketing of small businesses in the Russian Federation.

In the work of Zemlyak, it is noted that small businesses use marketing technologies implemented over the Internet (Zemlyak, 2007). The author refers to direct mail and electronic commerce. It is noted that other methods that meet the characteristics of low cost and low budget can also be used. 
The research of low-budget marketing communications by Tretyakova shows that small enterprises are guided by the minimum cost of contact with the target audience (Tretyakova, 2012). Such methods of Internet marketing as advertising in Russian Odnoklassniki and Vkontakte social networks are specified.

Sovershaeva's work is expanding her understanding of the communication methods of digital marketing (Sovershaeva, 2014). The author considers digital communications as a targeted interaction of the company with customers, carried out in an online environment.

Vaidyanathan and Aggarwal (2002) examine the origins of Internet marketing in small businesses. The authors point out that Internet marketing technologies allow small enterprises to reach the maximum number of potential consumers in a short time (Example: ebay).

Gilinsky et. al. (2003) come to a conclusion that the small business owners determine the Internet as a factor in the growth and success of their business. But only those of small enterprises achieve success that were able to combine their competencies in the selected market and the tools of Internet marketing. The problem of small enterprises in the Russian Federation is a low level of education in the field of Internet marketing (Sidorchuk, 2013). In the authors of this article opinion, it is necessary to combine the knowledge of small enterprises in the chosen field of activity and the methods of Internet marketing using an external marketing expert system.

Considering the impact of Internet use in small enterprises, Celuch et. al., (2014) indicate that the Internet is a highly demanded technology in case it has a positive effect on customer management and the financial results of the enterprise.

A study by Voelker used a simple binary system for testing the use of mobile website optimization technologies by small enterprises (Voelker et al., 2017). Based on an empirical survey of enterprises, it is noted that the more factors of mobile optimization are used on the website of a small enterprise, the higher the presence and visibility of the website's positions on the Internet.

Studies of the authors presented indicate that small businesses use Internet marketing methods and tools to provide a measurable result in sales without the use of extensive tools of Internet marketing analytics. Researchers also emphasize that a necessary element of the use of Internet marketing is the disposition of the small enterprise owner to the implementation of Internet marketing methods since this requires a change in the established and formalized processes of the organization.

In order to connect the considered theoretical provisions with the current level of development of Internet marketing in the Russian Federation, the authors of this article consider it necessary to indicate brief characteristics of online advertising usage in small businesses.

Based on a study by Roistat, the authors of this article examined the budget allocation and average return on investment of key advertising channels (Figure 1). 


\section{Budget allocation and average ROI of advertising channels in SMEs}

Share of advertising channels

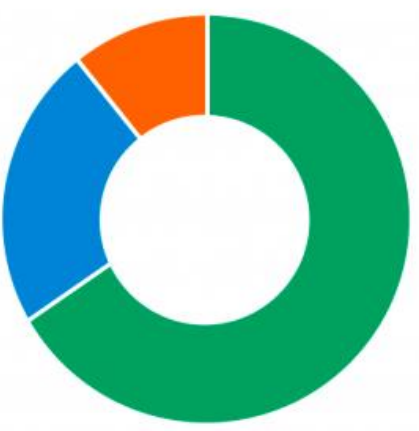

Average ROI of advertising channels

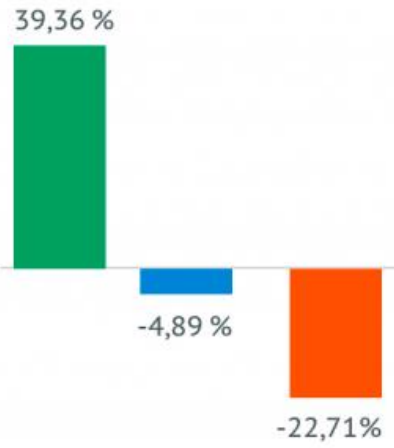

Figure 1. Budget distribution for Internet marketing in small enterprises of Russia

Source: https://roistat.com/ru/blog/issledovanie-kak-okupaetsya-internet

Figure 1 shows that the leader in the communication channels of Internet marketing for small businesses is search engine optimization (SEO) and contextual advertising (PPC). A study by Datainsight \& Avito (2017) examines what methods of Internet marketing are used by small businesses (Figure 2). The emphasis is on the study of Internet marketing methods of small enterprises and self-employed specialists.

\section{Small businesses enterprises use the channel, \%}

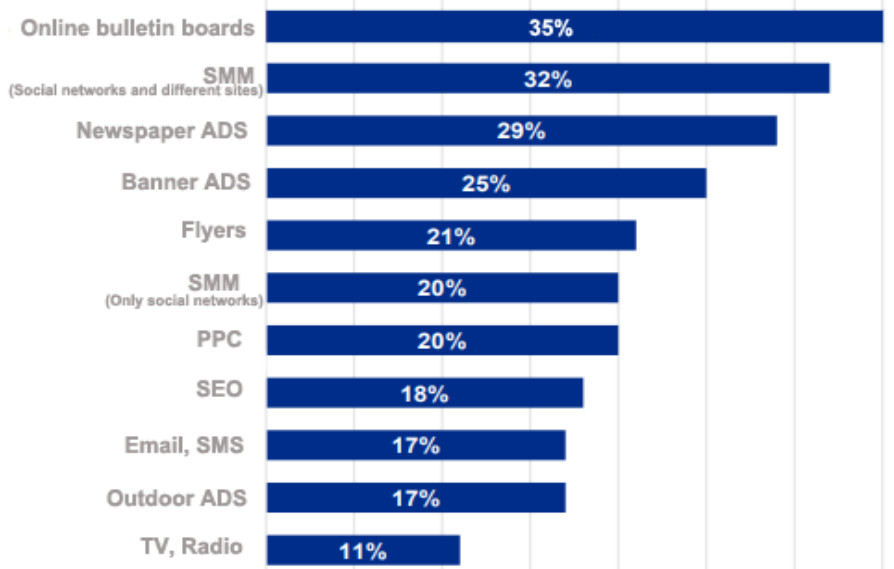

Figure 2. Internet marketing communication channels used by small enterprises of Russia Source: http://www.datainsight.ru/sites/default/files/avito-services.pdf

The considered statistics of Internet marketing usage in SMEs argues that various methods of Internet marketing are used. The main method is search engine optimization. Other methods complement and develop search engine optimization. Based on a theoretical study, the authors of this article assume that there may be particular cases in which the SEO method is not dominant. In the framework of the specifics of using the methods of Internet marketing and statistical research, let us note the hypothesis of the study.

H2: There are particular cases of using single communication channels that determine the high visibility of the website of a small enterprise.

H3: Internet marketing analytics systems are a prerequisite for the high visibility of small organization websites. 


\section{Methods}

This section of the study includes a set of procedures that describe the tools used to test the hypotheses of the study. The section includes research design development, data collection and sampling procedures.

\section{Design of the study}

Evaluation of the Internet marketing activities of small businesses is associated with features that determine the structure of the search for answers to research questions. Small businesses do not conduct systematic marketing activities (Zemlyak, 2007). The level of education of owners/key specialists of a small business in marketing and Internet marketing is low (Sidorchuk, 2013). These two factors determine that a direct survey of small business representatives cannot provide answers to research questions.

Owners and key specialists of small enterprises do not possess the necessary level of knowledge. Interviewing external structures, which include enterprises and specialists engaged in online marketing, is difficult. Because it is not always possible to clearly determine whether such an outsourcing company or specialist exists and arrange direct contact for the survey. Based on this specific work, the authors use the methods of sociological (Neuman, 2014) and marketing research. In the definition of the studied population, the sample description and its characteristics, the methods of sociological research are used. In order to process the data and characteristics of the studied units of the sample, the authors use marketing research methods. Following this logic of the study, factors were identified that determine the Internet marketing activity of small businesses. For an objective analysis of the characteristics of heterogeneous sampling units - small business enterprises, a cluster analysis was carried out and the dependencies between the small business website visibility, the number of Internet marketing methods used, the use of analytical methods, contextual advertising methods and social media promotion were determined.

\section{Data collection procedure}

The procedures for collecting and processing empirical data have been carried out for three months (September 2019 - November 2019). The study used a non-probabilistic (target) sample. This is related to the fact that there is no exact data on exactly how many companies are micro-enterprises and how many of them have their own website and use Internet marketing methods (seo, smm, ppc). For this reason, the authors of this study made the assumption that small micro-enterprises using Internet marketing methods most clearly demonstrate a sampled population. The argument for such a judgment is the study by Avito \& Datainsight (2017) stating that micro-enterprises are not likely to develop their website and apply appropriate methods of Internet marketing.

The authors of this work compiled a sample of small micro-enterprises based on statistical data from the geolocation service (2Gis, 2019) and checked for signs of conducting Internet marketing activities based on four markers (presented below).

In accordance with the objectives of this work, it is necessary to determine the types of Internet marketing methods that small businesses use. The authors of this article have developed a data collection table (Figure 3). The rows of the table are the methods of internet marketing and the level of visibility in search engine. The columns of the table are small enterprises from this study. If small enterprise uses the Internet marketing method, the number 1 is put in the table cell. If small enterprise does not use the Internet marketing method, the number 0 is put in the table cell. Thus, four markers were used (regarding the applicability of Internet marketing techniques). 
1. Visibility of key phrases in the main Russian-language search engine Yandex. Short designation - Visibility (V). This is the number of key phrases in the search engine by which the website is ranked. The analytical service serpstat.com is the data source (Serpstat, 2019). For clarity, determining the dependence of visibility on the methods used in Internet marketing, the visibility marker is divided into four categories - minimal (red - 0-10 queries), middle (orange - 11-50 queries), high (blue - 51-100 queries), very high (green - more than 100 queries).

2. The presence of analytical systems on the website of a small enterprise that allow measuring the effectiveness of Internet marketing methods. Short designation GA/YM. The source of the data is the analysis of the small enterprise website code based on the attributes of the system tag: <!--Google Analytics (Google Analytics, 2019), <!-Yandex.Metrika (Yandex.Metrika, 2019).

3. The presence of advertising campaigns in the search engine advertising networks of the main search engines of the Russian-speaking segment: Yandex and Google. The short designation is PPC. The presence of advertising companies determines the representation of microenterprises in the communication channel search engines (highlighted in the first part of the first chapter of the study). The analytical service serpstat.com is the data source (Serpstat, 2019).

4. The presence of the small organization's website pages in the main social networks of the Russian-speaking segment: Vkontakte and Odnoklassniki. Short designation - SMM. The presence of a page in a social network determines the representation of microenterprises in the social networks communication channel. The source of the data is the presence of the organization's page on a social network in Yandex search results for the following requests: "vk.com http://site-of-small-enterprise", "ok.ru http://site-of-small-enterprise" (https://site-of-small-enterprise is an example).

To account for these four markers, a data collection table has been developed. An example of a fragment of a completed table is shown in Figure 3.

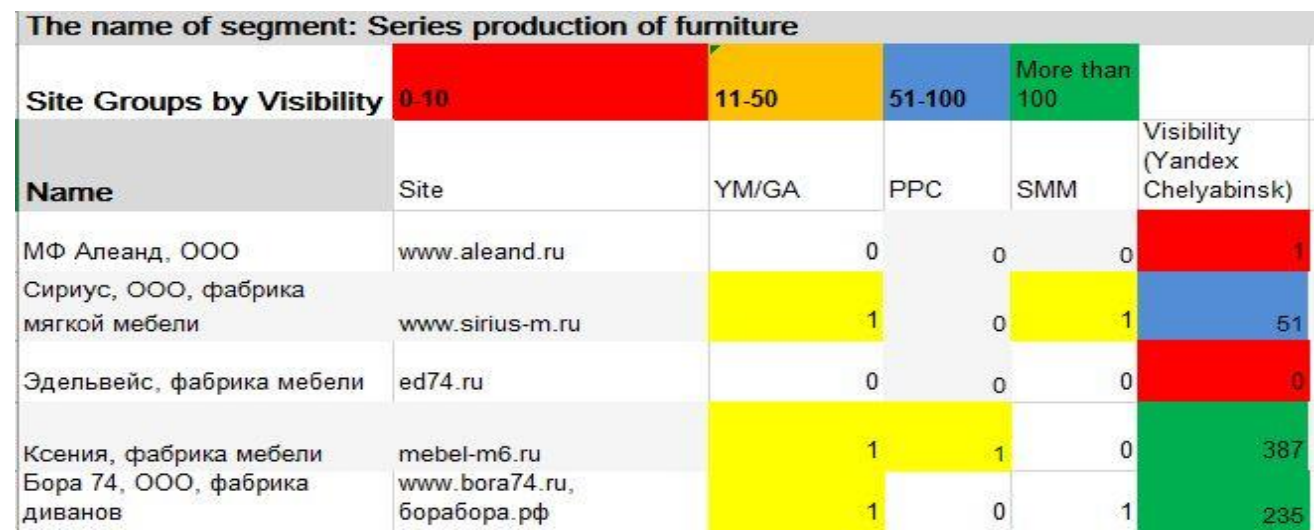

Notes: $Y M / G M$ - the number of small business enterprises websites used analytical system of internetmarketing; PPC - the number of small business enterprises websites used pay per click methods; SMM - the number of small business enterprises websites used social media marketing methods.

\section{Figure 3. Data collection table (Sample)}

Source: Authors' own research

\section{Sample}

In accordance with the research design, the websites of small micro-enterprises of the city of Chelyabinsk and the Chelyabinsk Region (Russian Federation) were selected as the unit of analysis. The production segment of small micro-enterprises was selected for research. Within the selected segment of small micro-enterprises, decomposition into sub- 
segments was carried out. Fourteen sub-segments were allocated relative to the main segment.

The following served as factors for including enterprises into the sample:

1. The presence of a website over 1-year-old. In accordance with the specifics of search engine optimization, age is one of the factors ranking the website.

2. The legal address, the address of registration with the tax authorities and the actual address relate to a single geographical criterion - Chelyabinsk Region.

3 . The number of employees is not more than 15 people. The factor is a criterion for classifying enterprises as small micro-businesses.

4. The marginal value of income for the reporting year is not more than 120 million rubles. The factor is a criterion for classifying enterprises as small micro-businesses.

5. Form of incorporation - a private enterprise or limited liability company.

Enterprises operating in the form of a joint-stock company are excluded from the sample due to the specifics of the legislation in classifying such enterprises as small businesses.

Factors are selected based on statistical data on small enterprises (Surinov, 2018). This list of five factors refines the study sample. This allows considering small microenterprises engaged in Internet marketing activities. Table 1 shows a list of small microorganizations with different levels of representation in communication channels and constituting a sample of this study.

Table 1. The sample of the current study

\begin{tabular}{|c|c|c|c|c|c|c|c|}
\hline \multirow[t]{2}{*}{ Name of subsegment } & \multicolumn{6}{|c|}{ Representation in communication channels } & \multirow{2}{*}{$\begin{array}{l}\text { Average } \\
\text { visibility } \\
\text { (queries) }\end{array}$} \\
\hline & $\begin{array}{l}\text { GA/YM } \\
\text { (units) }\end{array}$ & $\begin{array}{l}\text { GA/YM } \\
(\%)\end{array}$ & $\begin{array}{l}\text { PPC } \\
\text { (units) }\end{array}$ & $\begin{array}{l}\text { PPC } \\
(\%)\end{array}$ & $\begin{array}{l}\text { SMM } \\
\text { (units) }\end{array}$ & $\begin{array}{l}\text { SMM } \\
(\%)\end{array}$ & \\
\hline $\begin{array}{l}\text { 1. Production and wholesale } \\
\text { of auto parts }\end{array}$ & 59 & 28.6 & 7 & 16.7 & 27 & 29.7 & 63.6 \\
\hline $\begin{array}{l}\text { 2. Series production of } \\
\text { furniture }\end{array}$ & 4 & 1.9 & 2 & 4.8 & 4 & 4.4 & 88.1 \\
\hline 3. Graphite production & 7 & 3.4 & 2 & 4.8 & 0 & 0.0 & 6.25 \\
\hline 4. Foundry & 33 & 16.0 & 8 & 19.0 & 6 & 6.6 & 17.6 \\
\hline 5. Paper production & 5 & 2.4 & 1 & 2.4 & 3 & 3.3 & 89.7 \\
\hline 6. Plastic production & 13 & 6.3 & 4 & 9.5 & 10 & 11.0 & 63.3 \\
\hline 7. Cartographic production & 0 & 0.0 & 0 & 0.0 & 1 & 1.1 & 6.5 \\
\hline $\begin{array}{l}\text { 8. Scientific and production } \\
\text { organizations }\end{array}$ & 6 & 2.9 & 2 & 4.8 & 4 & 4.4 & 10.9 \\
\hline 9. Shoe manufacturing & 0 & 0.0 & 0 & 0.0 & 1 & 1.1 & 12.5 \\
\hline 10 Food production & 4 & 1.9 & 1 & 2.4 & 0 & 0.0 & 5.2 \\
\hline $\begin{array}{l}\text { 11. Manufacturing enterprises } \\
\text { (different types) }\end{array}$ & 65 & 31.6 & 11 & 26.2 & 27 & 29.7 & 23.8 \\
\hline 12. Fabric production & 1 & 0.5 & 0 & 0.0 & 0 & 0.0 & 18.5 \\
\hline 13. Plastic card production & 8 & 3.9 & 3 & 7.1 & 8 & 8.8 & 159.3 \\
\hline 14. Auto parts manufacturing & 1 & 0.5 & 1 & 2.4 & 0 & 0.0 & 13.0 \\
\hline $\begin{array}{l}\text { Total companies by } \\
\text { characteristic }\end{array}$ & 206 & 100.0 & 42 & 100 & 91 & 100 & - \\
\hline $\begin{array}{l}\text { Attitude to the number of } \\
\text { companies having a website }\end{array}$ & $\begin{array}{ll}206 & \text { of } \\
306 & \end{array}$ & 67.3 & $\begin{array}{l}42 \text { of } \\
306\end{array}$ & 13.7 & $\begin{array}{l}91 \text { of } \\
306\end{array}$ & 29.7 & - \\
\hline
\end{tabular}

Notes: YM/GM - the number of small business enterprises websites used analytical system of internetmarketing; PPC - the number of small business enterprises websites used pay per click methods; SMM - the number of small business enterprises websites used social media marketing methods.

Source: Authors' own research results 
In accordance with Table 1, the sample consisted of 306 small micro-enterprises engaged in Internet marketing activities. Of the 306 small micro-organizations in Chelyabinsk and the Chelyabinsk Region, 206 have an established analytical system (67.3\%), 42 enterprises use contextual advertising (13.7\%) and 91 enterprises use social networks to promote goods (29.7\%). Analysis of the visibility of search queries showed that on average in the Yandex search engine, Chelyabinsk Region, the minimum visibility is typical for enterprises producing food products (5.2 queries), the maximum visibility is typical for enterprises producing plastic cards (159.3 queries). In order to clarify certain hypotheses, let us move on to the analysis and findings section.

\section{Analysis and findings}

A cluster analysis of the formed sample was carried out in order to identify the dependence between Internet marketing methods within the framework of certain hypotheses. Groups of enterprises are distinguished depending on the applied methods of Internet marketing and the visibility of the websites of enterprises in search engines.

\section{Cluster analysis}

Each of the 4 categories of website visibility (from the minimum one: $0-10$ queries to the very high one: more than 100 queries) was further divided by the number of websites of small enterprises using 1 to 3 methods of Internet marketing, to make the minimum and maximum number of enterprises by category in each group obvious. For clarity, analytical Table 2 is compiled.

Table 2. Decomposition of small business websites visibility

\begin{tabular}{|c|c|c|c|c|c|}
\hline \multirow[t]{2}{*}{ Name of sub-segment } & \multicolumn{5}{|c|}{$\begin{array}{l}\text { Visibility in Yandex (V) / Representation markers in communication } \\
\text { channels from } 0 \text { to } 3(\mathrm{M})\end{array}$} \\
\hline & $\begin{array}{l}\text { V 0-10 / M 0-3 } \\
\text { (Minimal) }\end{array}$ & $\begin{array}{l}\text { V 11-50 / } \\
\text { M 0-3 } \\
\text { (Middle) }\end{array}$ & $\begin{array}{l}\text { V 51-100 / } \\
\text { M 0-3 (High) }\end{array}$ & $\begin{array}{l}\text { V > 100 / } \\
\text { M 0-3 (Very } \\
\text { High) }\end{array}$ & $\Sigma$ \\
\hline $\begin{array}{l}\text { 1. Production and wholesale of } \\
\text { auto parts }\end{array}$ & $\begin{array}{l}42 / 0-1(36) \\
2(6)\end{array}$ & $\begin{array}{l}27 / 0-1(16) \\
2(11)\end{array}$ & $7 / 0-1(4), 2(3)$ & $\begin{array}{l}8 / 1(2), 2(4) \\
3(2)\end{array}$ & 84 \\
\hline 2. Series production of furniture & $4 / 0-1(4)$ & $1 / 0-1(1)$ & $1 / 2(1)$ & $2 / 1(1), 2(1)$ & 8 \\
\hline 3. Graphite production & $6 / 0-1(5), 2(1)$ & $2 / 0-1(1), 2(1)$ & & & 8 \\
\hline 4. Foundry & $\begin{array}{l}22 / 0- \\
1(18), 2(4)\end{array}$ & $\begin{array}{l}13 / 0- \\
1(9), 2(4)\end{array}$ & $\begin{array}{l}3 / 0- \\
1(1), 2(1), 3(1)\end{array}$ & $1 / 3(1)$ & 39 \\
\hline 5. Paper production & $1 / 0-1(1)$ & $2 / 2(2)$ & $2 / 2(2)$ & $1 / 1(1)$ & 6 \\
\hline 6. Plastic production & $3 / 0-1(2), 2(2)$ & $7 / 1(3), 2(4)$ & $5 / 1(2), 3(3)$ & $3 / 1(1), 2(2)$ & 18 \\
\hline 7. Cartographic Production & $2 / 0-1(2)$ & & & & 2 \\
\hline $\begin{array}{l}\text { 8. Scientific and Production } \\
\text { Organizations }\end{array}$ & $10 / 0-1(6), 2(4)$ & $3 / 0-1(3)$ & $1 / 2(1)$ & & 14 \\
\hline 9. Shoe manufacturing & $1 / 0-1(1)$ & $1 / 0-1(1)$ & & & 2 \\
\hline 10 Food production & $9 / 0-1(9)$ & $2 / 0-1(2)$ & & & 11 \\
\hline $\begin{array}{l}\text { 11. Manufacturing enterprises } \\
\text { (different types) }\end{array}$ & $\begin{array}{l}59 / 0- \\
1(48), 2(8), \\
3(3)\end{array}$ & $\begin{array}{l}23 / 0-1(13) \\
2(8), 3(2)\end{array}$ & $\begin{array}{l}8 / 0-1(4), \quad 2(3) \\
3(1)\end{array}$ & $7 / 1(3), 2(4)$ & 97 \\
\hline 12. Fabric production & $1 / 0-1(1)$ & $1 / 0-1(1)$ & & & 2 \\
\hline 13. Plastic Card Production & $4 / 0-1(4)$ & $3 / 2(1), 3(1)$ & $1 / 3(1)$ & $\begin{array}{l}5 / 1(2), 2(2), 3( \\
1)\end{array}$ & 13 \\
\hline 14. Auto parts manufacturing & $1 / 0-1(1)$ & $1 / 2(1)$ & & & 2 \\
\hline$\sum$ sites of small enterprises & 165 & 86 & 28 & 27 & 306 \\
\hline
\end{tabular}

Notes: V - visibility of small business enterprises websites (number of queries in Yandex search engine, Chelyabinsk Region); $M$ - number of internet marketing methods used by small business enterprises websites 
Analytical Table 2 was used for additional decomposition of small enterprises using Internet marketing and visibility metrics. So, this allowed considering a detailed decomposition according to the principle below. An example is shown in Figure 4.

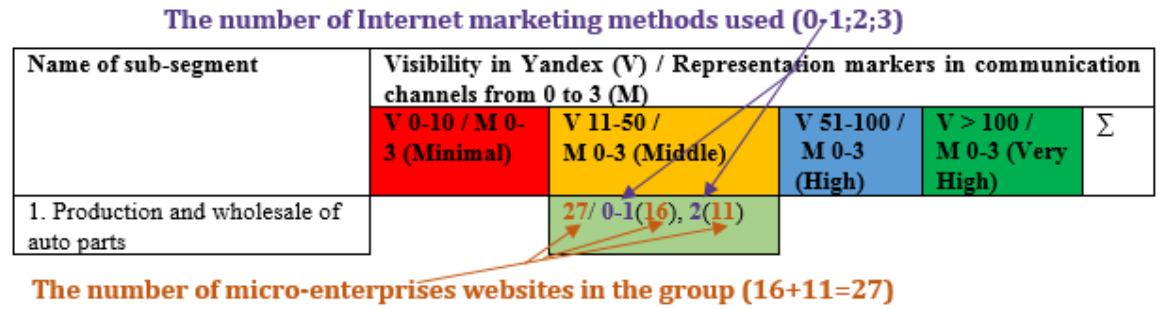

Notes: $V$ - visibility of small business enterprises websites (number of queries in Yandex search engine, Chelyabinsk Region); $M$ - number of internet marketing methods used by small business enterprises websites

Figure 4. Illustration for Table 2: example of internet sites separation

Source: Authors' own research

The sample of the study consisted of heterogeneous data: websites of small organizations, an indicator of visibility and three methods of Internet marketing. To order the sample and add clarity to analysis, the data were divided into three clusters:

Cluster 1 - there are 3 methods of Internet marketing present

Cluster 2 - there are 2 methods of Internet marketing present

Cluster 3 - there are 0-1 methods of Internet marketing present

Small enterprises that do not use Internet marketing methods are marked in white (an empty cell not included in any cluster) in groups with indicators of website visibility in search engines.

The division of enterprises into clusters is carried out according to the principle of applying the maximum number of Internet marketing methods. So, in Figure 4, the maximum number of Internet marketing methods in a cell is 2 , therefore, the cell belongs to the second cluster. Accordingly, 3 active clusters were identified according to the presence of Internet marketing methods.

Cluster No. 1: 3 methods of Internet marketing. Small businesses implementing three methods of Internet marketing belong to the group with medium visibility in search engines (11-50 queries), high visibility (11-50 queries) and very high visibility (more than 100 queries). Those are marked with yellow cells in the table.

Cluster No. 2: 2 methods of Internet marketing. Small businesses that implement two methods of Internet marketing apply to all groups of websites that are likely to appear in search engines. Those are marked with green cells in the table.

Cluster No. 3: implementing from 0 to 1 methods of Internet marketing. Small businesses that use from 0 to 1 Internet marketing methods belong to groups with minimal, medium and very high visibility in search engines.

The grouping of small business clusters by average visibility in the search engine and by communication channels representation markers considered in Table 1 looks like a $4 \times 14$ table (56 cells). Cluster 1 includes 10 table cells or $18 \%$ of the sample. Cluster 2 includes 19 table cells or $34 \%$ of the sample. Cluster 3 includes 13 table cells or $23 \%$ of the sample. Empty areas include 14 cells or $25 \%$ of the sample. Further, the detailed analysis of each of the groups presented was considered.

1) There are 7 active cells in the group of websites with very high visibility in search engines (from 100 requests and above). Of these, 3 cells (43\%) belong to cluster 1 , 3 cells (43\%) belong to cluster 2, 1 cell belongs to cluster $1(14 \%)$. 
2) There are 8 active cells in the group of websites with high visibility in search engines (from 51 to 100 queries). Of these, 4 cells belong to cluster 1 (50\%), 4 cells belong to cluster $2(50 \%)$.

3) There are 13 active cells in the group of websites with an average visibility in search engines (from 10 to 50 queries). Of these, 3 cells belong to cluster 1 (23\%), 6 cells belong to cluster 2 (46\%), 3 cells belong to cluster 1 (31\%).

4) There are 14 active cells in the group of websites with low visibility in search engines (from 0 to 10 queries). Of these, 6 cells belong to cluster 2 (43\%), 8 cells belong to cluster 3.

For further analysis and determination of the truth of hypotheses, a correlation analysis of the factors underlying the identified hypotheses was conducted. Based on the obtained value of the average visibility and representation of the websites of small organizations in communication channels (markers - minimal, middle, high, very high), a Spearman coefficient was calculated to determine the dependence of the values and a graphical interpretation was presented. The meaning of the constructs for analysis is presented in Table 3.

Table 3. The name and meaning of the analyzed constructs for small business enterprises (SBEs) sample

\begin{tabular}{|l|l|}
\hline Construct's name & Meaning \\
\hline Methods (M) & The number of digital marketing methods of SBEs sites applied in clusters \\
\hline Visibility (V) & Visibility in search engines of SBEs sites in clusters \\
\hline $\begin{array}{l}\text { Google } \\
\text { Analytics/Yandex.Metrika } \\
(\mathrm{GA} / Y M)\end{array}$ & $\begin{array}{l}\text { Availability of internet marketing analytical systems on SBEs sites in } \\
\text { clusters }\end{array}$ \\
\hline Methods of PPC (PPC) & Use of contextual advertising methods by SBEs sites in clusters \\
\hline Methods of SMM (SMM) & Use of social media marketing methods by SBEs sites in clusters \\
\hline
\end{tabular}

Source: Authors' compilation

Table 4. Squares of the correlation between constructs (Pearson's coefficient)

\begin{tabular}{|l|l|l|l|l|l|}
\hline Construct's name & (M) & (V) & (GA/YM) & (PPC) & (SMM) \\
\hline$(\mathrm{M})$ & 1.00 & & & & \\
\hline$(\mathrm{V})$ & 0.91 & 1.00 & & & \\
\hline$(\mathrm{GA} / \mathrm{YM})$ & -0.98 & -0.98 & 1.00 & & \\
\hline$(\mathrm{PPC})$ & 0.98 & 0.82 & -0.92 & 1.00 & \\
\hline$(\mathrm{SMM})$ & 0.87 & 0.99 & -0.95 & 0.76 & 1.00 \\
\hline
\end{tabular}

Source: Authors' calculation in database

Table 4 shows the correlation results for the studied variables. The number of Internet marketing methods used $\mathrm{M}$ positively correlates with the visibility of Internet sites $(r=0.91)$. Further, following the results of the table, visibility (V) is positively correlated with the use of PPC contextual advertising methods $(r=0.91)$ and SMM social media promotion $(r=0.87)$. The results also show that the use of GA/YM analytic systems negatively correlates with the visibility of websites $\mathrm{V}$. Next, let us turn to a graphic illustration of hypotheses and elements of cluster analysis, which in the case of this study will reflect the obtained results more clearly.

H1 - Confirmed. There is a dependency between the number of communication channels, Internet marketing methods and website visibility in a search engine. Illustrations to this conclusion are presented in Figure 5. 


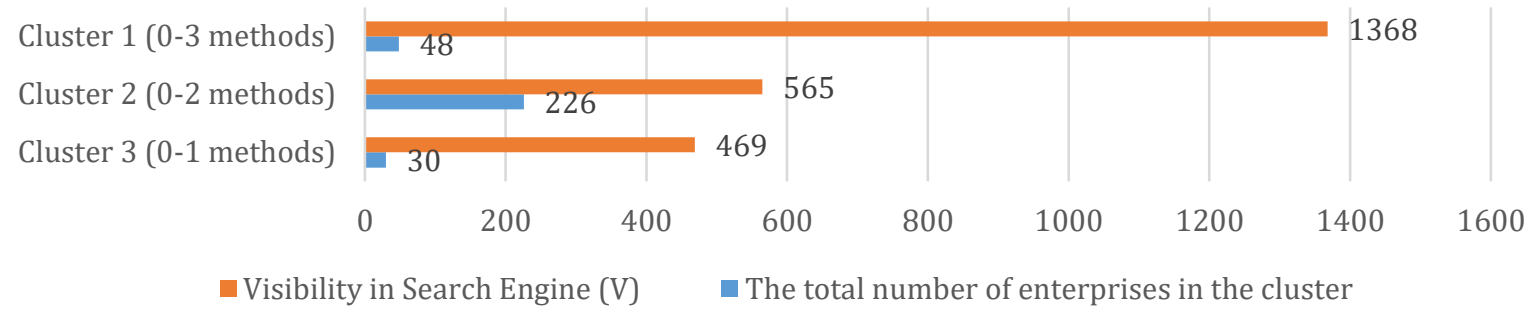

Figure 5. The dependence between visibility in search engines (V) and numbers of internet marketing methods (M) used by small business enterprises clusters

Source: Authors' own research results

Hypothesis $\mathrm{H} 2$ - confirmed. With the minimum number of Internet marketing methods used, the visibility of small enterprises' websites is high. The data presented in Table 2 shows that $20.2 \%$ of the analyzed enterprises do not use analytical systems or contextual advertising, but have active groups in social networks. Additional correlation analysis of the results shows that the dependence of Visibility and PPC (V-PPC) is high (a value of 0.82 ) and the dependence between Visibility and SMM (V-SMM) is high (a value of 0.99). Illustrations to this conclusion are presented in Figure 6 and Figure 7.

Figure 6. The dependence between visibility in search engines (V) and contextual advertising methods (PPC) used by small enterprises clusters

Source: Authors' own research results

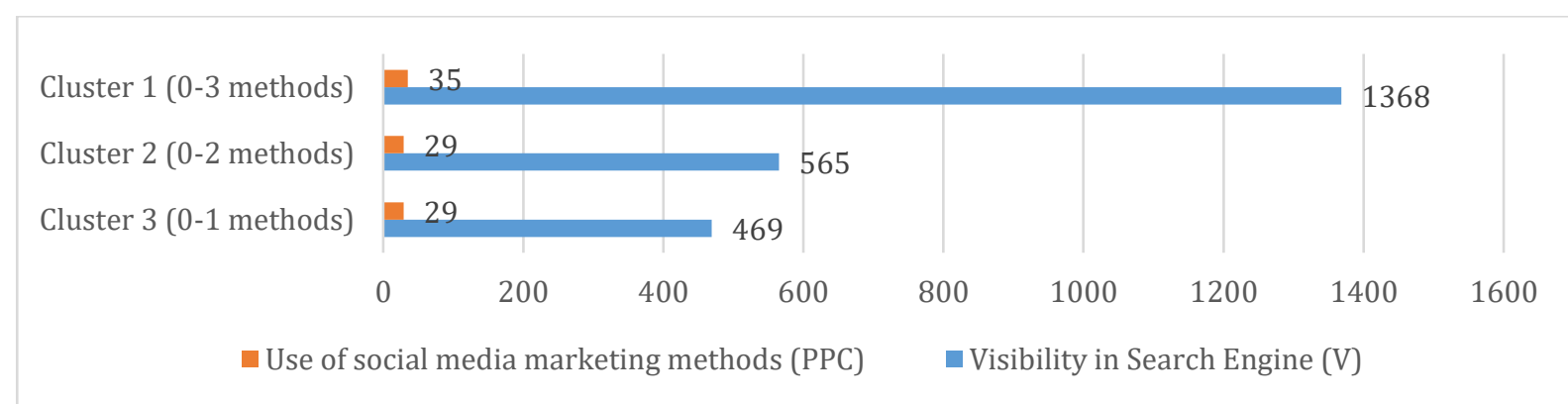

Figure 7. The dependence between visibility in search engines (V) and social media marketing methods (SMM) used by small enterprises clusters

Source: Authors' own research results

Hypothesis H3 - not confirmed. On the one hand, the graph in Figure 5 and the negative correlation in Table 4 show the dependence. However, on the other hand, a detailed analysis of the research data shows that the number of enterprises with minimal visibility in search engines (from 0 to 10 units) exceeds the number of enterprises with visibility of 50 or more units (Figure 8). 


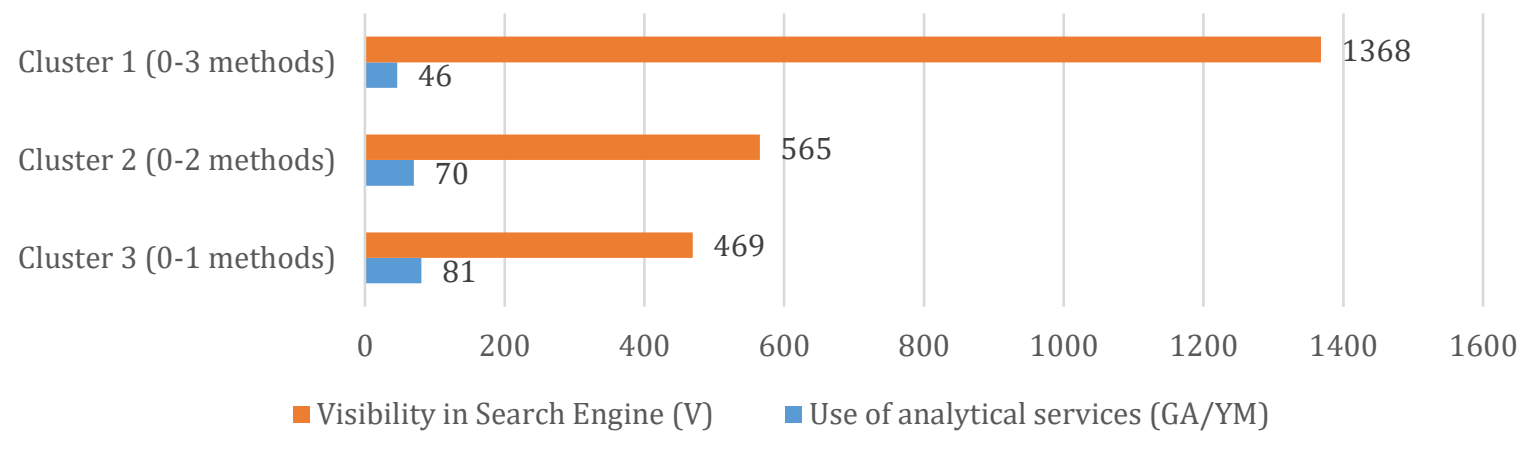

Figure 8. The dependence between visibility in search engines (V) and analytic systems (GA/YM) used by small enterprises clusters

Source: Authors' own research results

The number of small enterprises with minimal visibility in search engines (minimum group) having a counter of one of two systems - Google Analytics or Yandex.Metrika exceeds the number of websites of all other groups (middle, high, very high). Figure 9 illustrates this argument.

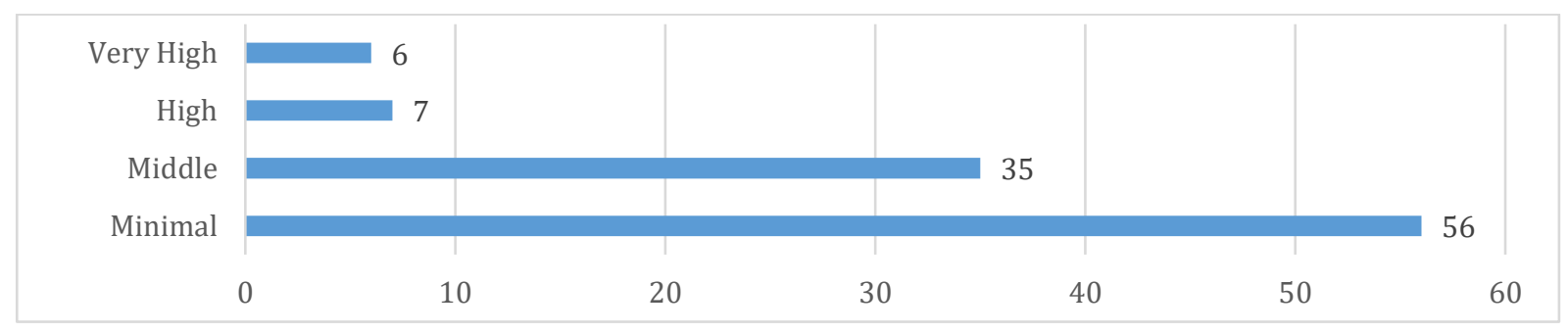

Figure 9. Small enterprises using only analytical systems (this method is the only one)

Source: Authors' own research results

Consideration of small organizations that do not use Internet marketing methods other than counters (GA/YM) analytically shows the following results. The Minimal group includes 56 enterprises (33.9\% of the whole group), the Middle group includes 35 enterprises (40.7\% of the whole group), the High group includes 7 enterprises $(25 \%$ of the whole group), the Very High group includes 6 enterprises (22\% of the whole group).

To extrapolate the presented case of small micro-enterprises in the Chelyabinsk region, the development of Internet technologies in the Russian Federation is considered in relation to the global community. The development of Internet technologies depends on the level of Internet penetration (Figure 10).

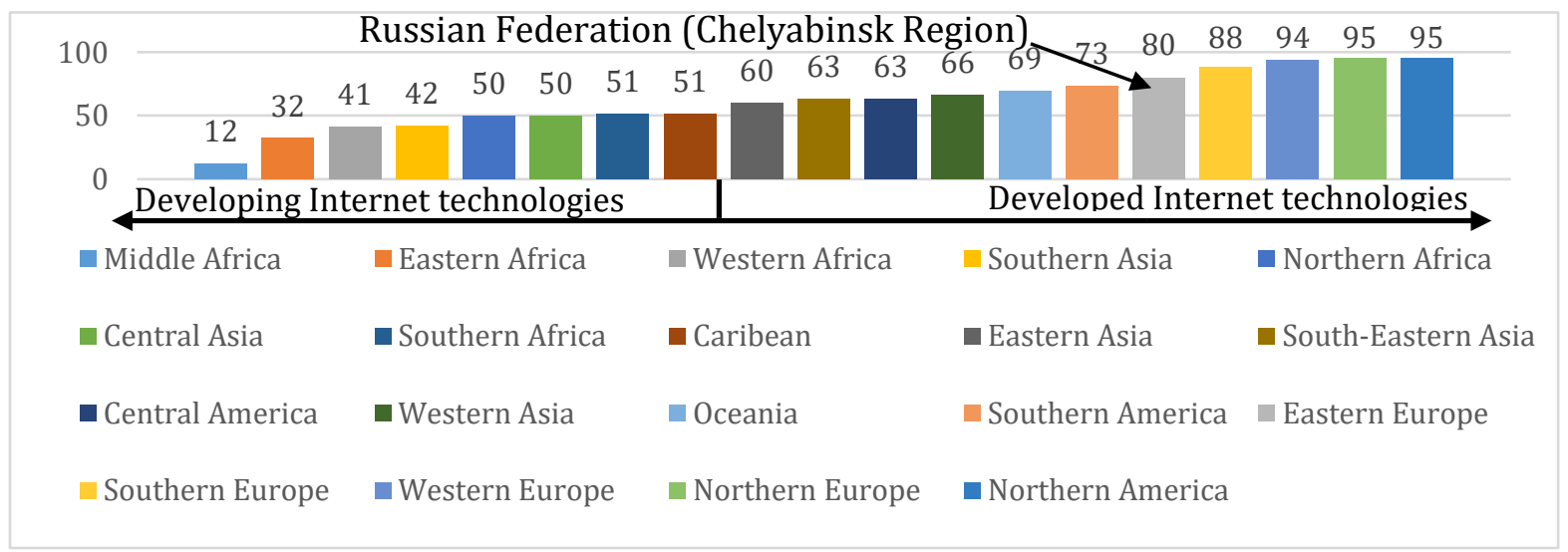

Figure 10. Internet penetration by region, \%

Source: https://datareportal.com/reports/digital-2018-global-digital-overview (Authors' compilation) Vol. 15, No. 1, Spring, pp. 38-58, ISSN 2069-8887| Management \& Marketing. Challenges for the Knowledge Society 
Figure 10 shows that the countries of Eastern Europe, to which the Russian Federation (including the Chelyabinsk region) belongs are characterized by a high level of Internet technology penetration. But, the penetration of Internet technology does not mean the development of electronic commerce (Figure 11).

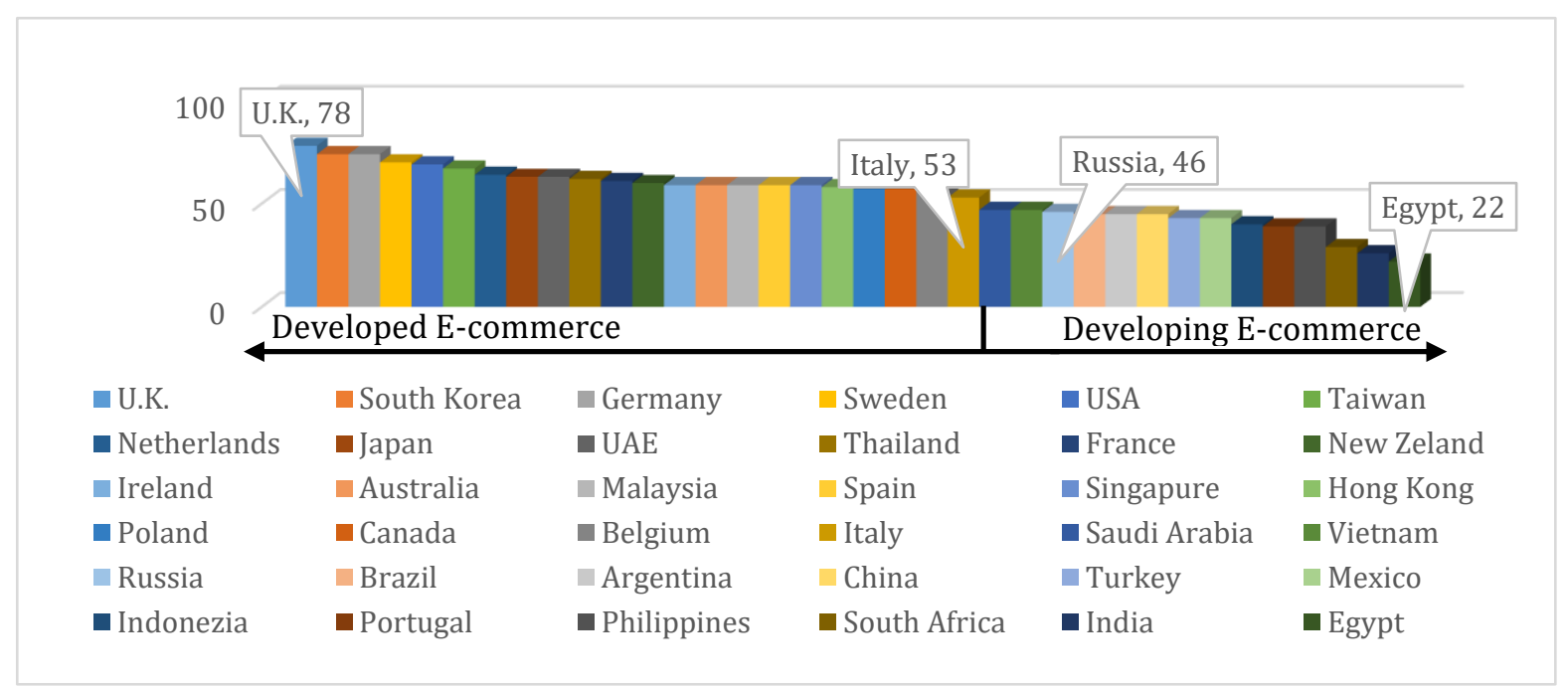

Figure 11. E-commerce penetration by country, \%

Source: https://datareportal.com/reports/digital-2018-global-digital-overview (Authors' compilation)

Figure 11 shows that despite the high level of penetration of Internet technologies, the level of e-commerce (the use of Internet technologies in marketing) is low. In relation to this study, this means that search engine results are dynamic, with less competition and greater opportunities to promote and increase the visibility of the websites of small micro-enterprises. A generalized conclusion is presented in Table 5, which describes the ideas of this study in relation to the development of small micro-enterprises in other countries of the world.

Table 5. The activities of small micro-enterprises and the improvement of Internet marketing technologies (SME's world context)

\begin{tabular}{|l|l|l|}
\hline \multicolumn{1}{|c|}{ IT } & $\begin{array}{l}\text { Developed Internet Technologies } \\
\text { (IT) }\end{array}$ & $\begin{array}{l}\text { Developing Internet Technologies } \\
\text { (IT) }\end{array}$ \\
\hline $\begin{array}{l}\text { Developing E-commerce } \\
\text { (EC) }\end{array}$ & 1) Website & 3) Website \\
\hline $\begin{array}{l}\text { Developed E-commerce } \\
(\text { EC) }\end{array}$ & $\begin{array}{l}\text { 2) Website and other } \\
\text { communication channels }\end{array}$ & $\begin{array}{l}\text { 4) Website and other communication } \\
\text { channels }\end{array}$ \\
\hline
\end{tabular}

Source: Authors' research results

Block 1 - website development. Developed Internet technologies and developing e-commerce. Examples of countries: Russia, Argentina, Saudi Arabia and etc. Distinctive features: the average level of competition in search results, the average level of aggregation of search results (the presence of large aggregator websites). The pace of the visibility increase of a small enterprise website in search engines: medium-high.

Block 2 - development of the website and other communication channels. Developed Internet technologies and developed e-commerce. Examples of countries: USA, Germany, France and etc. Distinctive features: a high level of competition in search results, a high level of aggregation of search results (the presence and high level of development 
of large aggregator websites). The pace of the visibility increase of a small enterprise website in search engines: low.

Block 3 - website development. Developing Internet technologies and developing e-commerce. Examples of countries: Egypt, India, Indonesia and etc. Distinctive features: low level of competition in search results, low level of aggregation of results (the presence of large aggregator websites in a number of market niches). The pace of the visibility increase of a small enterprise website in search engines: high.

Block 4 - development of the website and other communication channels. It is the rarest type in this classification. E-commerce development is impossible without the development of Internet technology. But, theoretically, this block can exist in countries with a high level of social inequality (income differentiation). E-commerce is developing only in large cities, while the rest of the country does not have access to Internet technologies, such as in South Africa, Philippines, Haiti etc. Distinctive features: low, medium level of competition in search results, low-medium level of aggregation of search results (depends on the city / region under study). The pace of the visibility increase of small organization website in search engines: low, medium, high (depending on the city / region under study).

Thus, extrapolating the results of this study on a global scale of small enterprises shows four scenarios regarding the development of Internet technologies and the level of e-commerce. Developed Internet technologies for marketing and e-commerce increase the complexity of promoting an Internet website, but provide the opportunity to develop visibility in alternative communication channels - search aggregator websites.

\section{Discussion and Conclusions}

This study promotes the understanding of the use of Internet marketing technologies by small micro-businesses. The study describes the application of three Internet marketing methods: analytical methods (GA/YM), contextual advertising (PPC) and social networks promotion (SMM) connected by a single construct - the visibility of the website in the communication channels (V). In accordance with the study, the following conclusions are made.

First, there is a difficulty in understanding the factors affecting the effectiveness and efficiency of conducting Internet marketing activities by small micro business enterprises. The owners of such enterprises do not possess the necessary level of competencies in order to adequately characterize the Internet marketing activities of the enterprise, as presented in Sidorchuk (2013). In this regard, the choice of factors - the methods of Internet marketing - allows characterizing Internet marketing activities remotely.

Second, there is a difficulty in measuring and formalizing research data. The closed nature of activity does not allow for full-fledged marketing research. The low competence of small business owners in Internet marketing does not allow obtaining reliable research data through a sociological survey. The compilation of elements of marketing analysis and sociological research proposed in this work allows studying small businesses in terms of characteristics that are reflected in the Internet marketing communication channels.

The study revealed the dependence between the Internet marketing methods variables: PPC-V, SMM-V, GA/YM-V. The following facts are worth noting if the dependence between the use of contextual advertising and the visibility of a website in search engines (PPC-V), the use of promotion methods on social networks and visibility in search engines are considered. 
In the authors' opinion, the positive relationship of the described factors was ensured not by the availability of methods, but by the results of their use. The information flow (in practical terms, website traffic) arising from the use of Internet marketing methods stimulates the behavioral factors of the website (the activity of visitors to this website) and gives a signal to search engines about a positive ranking ( $\mathrm{H} 1$ and $\mathrm{H} 2$ ). Related studies in this area are presented by Halligan and Shah (2014), but for widespread use of the various communication channels that make up the inbound marketing methodology.

In the authors of this study opinion, more interesting results were obtained by studying the dependence between the use of analytical systems and the visibility of websites (H3). The results of the study revealed a dependence between constructs. The detailed analysis showed that the presence of an analytical system on a website is the marker for a search engine that notes the development trends of a website. If the methods of Internet marketing are applied effectively, the visibility of the website increases. Tracking results requires an analytical system. For this reason, the smallest percentage of lacking analytical systems was found among enterprises with a high percentage of visibility in search engines.

\section{Theoretical implications}

The study argues the further digitalization of the marketing concept. On the one hand, competition even among small enterprises moves to the levels of communication channels of Internet marketing that transfer the right to start interacting with the company to the consumer (search engines, social networks, video hosting, etc.). On the other hand, the rules of conduct in communication channels are changing faster than in classical marketing. Commenting on this conclusion, the authors believe that digital marketing research should have a common basis, which is the integral characteristic of the consumer from various communication channels. Based on a theoretical study in this paper, the authors assume that the information flow is such a basis.

Consideration of the information flow of Internet marketing allows disengaging from the specifics of the communication channel (transmitting this segment into the field of practice-oriented research) and moving to the study of the consumer as a unit of the target audience, undergoing transformation through communication channels into the buyer and client of the organization. In the authors' opinion, research on the Internet marketing activities of small enterprises should be based on the study of the advantages of broadcasting value in various communication channels and the study of the connections arising from the interaction of Internet marketing methods in communication channels.

\section{Practical implications}

For small and micro business owners, this study can be useful from two points of view. First, it is necessary to take into account the popularity trend of the communication channel and follow the consumer. As part of the study, it was determined that there are special cases of using individual methods of Internet marketing. So, an Internet site can have one active group in social networks, providing high behavioral factors and affecting the promotion of the website. Second, leadership in one communication channel is not permanent. A single communication channel does not provide stability. Changes in search algorithms, negative changes in the formats for delivering content on social networks, contextual advertising can jeopardize a steady influx of buyers for a small enterprise (especially in conditions of lack of financial resources). Therefore, a minimum presence 
in the maximum number of communication channels is required, which allows switching to other channels in the case of problems.

In the authors of this study opinion, the best practice is to share efforts between different communication channels, ensuring a minimum presence in the communication channel (for example, the business owner independently maintains a page on the Instagram social network) and using the services of third-party specialists for additional practices (using the services of freelancers to organize an advertising campaign on a social network). This approach extends the proposed options for a marketing expert entity (Sidorchuk, 2013) to the plane of Internet marketing.

The authors of this article extrapolated the results of an empirical study on the worldwide Internet marketing activities of small micro organizations. Four levels of conducting Internet marketing activities based on the development of Internet technologies and ecommerce are described. The more developed are Internet technologies and e-commerce, the more difficult it is for a small business to gain visibility in search engines. But, at the same time, there are more opportunities to use alternative methods of Internet marketing and communication channels (trading aggregators - ebay, amazon, etc.).

\section{Limitations and suggestions for future research}

Despite the results, this study has some significant limitations. Limitations and possible directions for future research are defined below.

The first limitation is based on the composition of the sample. The sample size ( $\mathrm{n}$ = 306) reflects the application of Internet marketing methods by small businesses of one segment (production) within one region (Chelyabinsk Region, Russia). Therefore, the conclusions of this study cannot be generalized widely. For future research, the sample should be larger and include several related business segments of small businesses.

The second limitation is based on the use of research methods. The combination of marketing research and sociological survey yielded results in the form of research data. However, the presence of selective interviews with representatives of small businesses from different fields of activity could supplement the data already presented. Future research should use a combination of the presented approach and selective interviews with small businesses.

The third limitation is associated with the use of a simplified methodology for studying the characteristics of websites. It should be noted that in addition to those presented in the work, the characteristics of search engine optimization such as the age of the website, the link profile, the quality of text content optimization and other factors can affect the visibility of Internet sites. Also, in the authors' opinion, the connection of these factors with the financial results of small enterprises is worth exploring in more detail. Therefore, in further studies, a more complex, multifactorial model that takes into account the specifics presented is needed. In addition, it should be kept in mind that the study presents the results at a certain point in time and that the websites that formed the composition of the sample may change, lose or acquire new characteristics in the future.

Thus, future research may include these limitations in order to obtain new research results.

\section{Conclusion}

Small enterprises are one of the foundations of economic development - they provide jobs and ensure economic growth. The digitalization of marketing elements is an integral process of the digital economy. The emergence of new specific elements - the methods of Internet marketing, determines the need for their study for small businesses enterprises. 
In this study, the goal was to examine the conceptual and empirical relationship between analytical methods of Internet marketing (GA/YM), methods of social networks promotion (SMM), methods of contextual advertising (PPC) and such a variable as the visibility of Internet websites (V).

The study shows that there is an empirical connection between methods of promotion in social networks, contextual advertising methods, and the visibility of Internet websites (V). The conceptual meaning of this is that the Internet marketing activities of small enterprises can be considered as a subspecies of the marketing stream - the information stream of Internet marketing, converting units of the target audience into buyers and clients of a small organization. Further research of determining the connection between Internet marketing methods and the financial results of a small business is required.

\section{Acknowledgment}

Research has been performed with the support of the Russian Foundation for Basic Research, grant No. 19-310-90021 "Research of information flows interaction in the aspect of Internet marketing technological essence formation in small businesses".

\section{References}

Bagiev, G. (2009). Conceptual foundations of interaction marketing formation in the development of market networks. Problems of Modern Economics, 32(4), 271-275.

Berdyshev, S. (2010). Information marketing. Practical guide. Moscow: Dashkov \& Co.

Berman, R., \& Katona, Z. (2012). The Role of Search Engine Optimization in Search Marketing. Marketing Science, 32 (4), 644-651.

Celuch, K., Bourdeau, B., Saxby, C., \& Ehlen, C. (2014). SME Internet USE: The Moderating Role of Normative Influence. Journal of Small Business Strategy, 24(2), 69-90.

De Cleen, P (2018). Flow marketing: Content, Conversatie, Conversie: Go with the flow. Amsterdam: Lannoo Campus.

Fathalla, S., Vahdati, S., Lange, S., \& Auer, S. (2019). SEO: A Scientific Events Data Model. 18th International Semantic Web Conference. Proceedings. Part II, October 26-30 2019, Auckland, New Zealand.

Gilinsky, A., Thach, E., \& Thompson, K. (2003). Connectivity \& Communication: A Study of How Small Wine Businesses Use the Internet. Journal of Small Business Strategy, 14(2), 37-57.

Halligan, B., \& Shah, D. (2014). Inbound Marketing: Attract, Engage, and Delight Customers Online ( $2^{\text {nd }}$ ed.). Upper Saddle River, NJ: John Wiley \& Sons.

Hamdar, B., Aridi, E., \& Mroueh, R. (2018). The economics of search engine visibility and its relation to brand perception: implications for Lebanese consumers. International Journal of Economics, Commerce and Management, 6 (4), 585-606.

Hamdulay, Z., \& Weideman, M. (2006). Search engine visibility: the effect of generic toplevel domain choice. Proceedings in the 8th Annual Conference on WWW Applications, 5-8 September 2006, Bloemfontein, South Africa.

Kapustina, L., \& Mosunov, D. (2015). Internet Marketing. Theory and practice of brand promotion on the web. Yekaterinburg: Ural State University of Economics.

Kaya, H. (2019). Internet Usage in Entrepreneurial Process and Firm Characteristics. Journal of Applied Economic Sciences, 13(1), 43-52.

Kotler, P., \& Keller, K. (2012). Marketing Management (14th ed.). Upper Saddle River, NJ: Prentice Hall. 
Krstic, N. (2019). The Relationship Between Website Management and Search Engine Optimization. Megatrend revija, 16(2), 155-168.

Lambin, JJ., \& Schuiling, I. (2012). Market-Driven Management: Strategic and Operational Marketing (3rd ed.). New-York, NY: Palgrave Macmillan.

Levinson, J. (2007). Guerilla Marketing: Easy and Inexpensive Strategies for Making Big Profits from Your Small Business (4th ed.). New-York, NY: Houghton Mifflin Harcourt.

Neuman, L. (2014). Social research methods: qualitative and quantitative approaches. (7th ed.). Edinburgh: Pearson Education Limited.

Novak, T., Hoffman, D., \& Yung, Y. (2000). Measuring the Customer Experience in Online Environments: A Structural Modeling Approach. Marketing Science, 13(1), 22-42.

Sidorchuk, R. (2012). Model of Marketing Expert System in the Structure of Small and Medium Enterprises. Marketing in Russia and Abroad, 15(6), 3-18.

Slivar, I., \& Doric, B. (2011). Search Engine Visibility of National and Regional DMO Websites in Europe. Second International Scientific Congress - Biennale „The Influence of Tourism on Economic Development", 12, 767-772.

Soegoto, S., \& Simbolon, T. (2018). Inbound Marketing as a Strategy in Digital Advertising. IOP Conference Series: Materials Science and Engineering. Retrieved from: https://iopscience.iop.org/article/10.1088/1757-899X/407/1/012183/pdf

Sovershaeva, S. (2014). Evaluation of the digital marketing communications performance. Saint-Petersburg: Saint-Petersburg State University of Economics.

Surinov, A (2018). Russian Statistical Yearbook 2018. Moscow: Rosstat.

Tretyakova, T (2012). Development of modern companies marketing communication complex based on low-budget technologies. Rostov on Don: Southern Federal University.

Vaidyanathan, R., Aggarwal, P. (2002). The Impact of Shopping Agents on Small Business E-Commerce Strategy. Journal of Small Business Strategy, 13(1), 63-79.

Voelker, T., Steel, D., \& Shervin E. (2017). Internet presence as a small business capability: the case of mobile optimization. Journal of Small Business Strategy, 27(2), 90-103.

Weideman, M. (2005). Search engine visibility: a pilot study towards the design of a model for e-commerce websites. Proceedings of the 7th Annual Conference on WWW Applications, 29-31 August 2005, Cape Town, South Africa.

Zemlyak, S. (2007). Management of marketing technologies in the field of small business (problems, theory, practice). Moscow: ARDLIFE.

***Research: how Internet advertising pays off in Russia, https://roistat.com/ru/blog/issledovanie-kak-okupaetsya-internet (retrieved 15 September, 2019)

*** Private enterprise and small business in the services market,

http://www.datainsight.ru/sites/default/files/avito-services.pdf (retrieved 7 October, 2019)

***2gis - Map of Russia cities. Retrieved from: https://2gis.com (retrieved 1 October, 2019)

***Serpstat - Growth hacking tool for SEO, PPC and content marketing, https://serpstat.com/ (retrieved 3 October, 2019)

***Google Analytics, https://analytics.google.com (retrieved 5 September, 2019)

***Counters - Yandex. Metrika, https://metrika.yandex.ru (retrieved 5 September, 2019)

***Digital 2018: Global digital Overview, https://datareportal.com/reports/digital2018-global-digital-overview (retrieved 7 February, 2020) 